\title{
Exploring the link between depression and accelerated cellular aging: telomeres hold the key
}

\author{
This article was published in the following Dove Press journal: \\ Research and Reports in Biochemistry \\ 22 December 2015 \\ Number of times this article has been viewed
}

\section{Ruby Yu \\ Jean Woo}

Department of Medicine and Therapeutics, The Chinese University of Hong Kong, Hong Kong, SAR, China
Correspondence: Ruby Yu

Department of Medicine and

Therapeutics, The Chinese University

of Hong Kong, Hong Kong, SAR, China

Tel +852 26322190

Fax +852 26379215

Email rubyyu@cuhk.edu.hk

\begin{abstract}
Accumulating evidence suggests that telomeres may be a marker for biological aging and telomere length may be affected by multifactorial influences, including cumulative exposure to depression. Associations with telomere length have been reported for major depressive disorder, lifetime duration of depression, higher depression severity, and history of depression. The exact underling mechanisms for these associations have yet to be fully elucidated; however, oxidative stress, chronic inflammation, dysregulated hypothalamus-pituitary-adrenal axis, and altered cortisol levels may be important biochemical mediators. These mediators could also be influenced by psychological stress, unhealthy lifestyle behaviors, or other potential factors, such as childhood abuse, post-traumatic stress disorder, and anxiety that are commonly associated with depression. As such, stress reduction and lifestyle interventions that may affect the telomere maintenance system should be considered for individuals with depression.
\end{abstract}

Keywords: depression, telomere length, biomarkers, cellular ageing

\section{Telomerase activity, telomere length, and aging}

Telomeres are specialized nucleoprotein structures located at the end of eukaryotic chromosomes, which consist of double-stranded tandem DNA repeats and a multitude of associated proteins. They play a critical role in controlling cell proliferation and maintenance of chromosomal stability. ${ }^{1}$ However, telomeric DNA repeats can be lost during every cell division, therefore, telomeres progressively shorten and ultimately leads to replicative senescence and subsequent cell death. ${ }^{2,3}$ Nevertheless, telomere shortening can be counteracted by telomerase, a ribonucleoprotein enzyme, which contains an essential RNA component (telomerase RNA component) that serves as a template and as a catalytic subunit of telomerase (telomerase reverse transcriptase) that is required for the synthesis of new telomeric DNA repeats to be added to the end of chromosomes. ${ }^{4}$

Telomerase is expressed at high levels in cells of the germinal line, stem cells, and some leukocytes but repressed in most somatic cells beyond the early stages of fetal development. ${ }^{5,6}$ In proliferating cells lacking telomerase, telomeres progressively shorten during every mitotic division, and this progressive telomere loss eventually leads to critically shorter telomeres, which triggers a DNA damage response that results in chromosomal end-to-end fusions or cell arrest and apoptosis, which the cell population as a whole eventually undergoes senescence.

Telomeres naturally lose approximately $30-150$ bp with each cell division ${ }^{3}$ and its length is highly variable among individuals at the same age and to a large extent genetically determined, with heritability estimates ranging from $40 \%$ to $80 \%{ }^{7}$ There are 
no sex differences in telomere length at birth, but thereafter, males tend to have shorter telomeres than females. ${ }^{8,9}$ Short telomeres can lead to chromosomal instability, which can increase the rates of genetic mutations and chromosome abnormalities. ${ }^{10}$ This loss of cell viability associated with telomere shortening is thought to contribute to the onset of degenerative diseases that occur during human aging. ${ }^{11}$

Telomere length has been associated with aging and several age-related diseases. For example, several signs of geriatric syndrome, such as delayed recall and verbal fluency, ${ }^{12}$ lower grip strength, ${ }^{13}$ and age-related diseases, including cardiovascular disease, ${ }^{14}$ type 2 diabetes, ${ }^{15}$ neurological disease, ${ }^{16}$ as well as cancer ${ }^{17}$ are characterized by the presence of short telomeres, probably reflecting the past proliferative history to apoptosis and senescence and suggesting that it might be an indicator for the underlying mechanisms that bring about aging.

Indeed, telomere length is not merely a biomarker of agerelated diseases, but also a potential determinant of lifespan. Animal studies demonstrated that telomere shortening and lower telomerase activity are causes of metabolic and mitochondrial damage, ${ }^{18}$ and that telomerase reactivation reversed tissue degeneration. ${ }^{19}$ In human, inverse association between the telomere length and risk of death from heart disease or infections has been observed. ${ }^{20}$ A sample of elderly Swedish twins confirmed these findings by demonstrating that shorter telomere length was related to a higher risk of mortality, independent of early familial environment, and genetic factors. ${ }^{21}$ Similar results were reported from the elderly Danish twin cohort, where the co-twin with the shorter telomeres died earlier than their counterparts, further suggesting that telomere length might directly contribute to longevity. ${ }^{22}$ However, other studies did not confirm this finding. ${ }^{23-25}$

Recently, the concept of frailty, as an indicator of biological age as opposed to chronological age was developed. It is characterized by the loss of physiologic reserves and increased vulnerability to functional impairment and age-related diseases. ${ }^{26-28}$ Recent literature has suggested inflammatory processes as an underlying mechanism for frailty. ${ }^{29,30}$ Therefore, telomere shortening may also be associated with frailty. In support of this idea, the association between telomere length and frailty has been studied in a sample of Chinese men and women aged 65 years and above. Although women were frailer than men, they had a longer telomere length. In men only, frailty index was positively associated with mortality. However, there was no association between telomere length and frailty index in either sex. ${ }^{31}$ Other studies also found no correlation between telomere length and frailty index. ${ }^{32,33}$

\section{Associations between depression and telomere length}

While many age-related diseases such as cardiovascular disease,${ }^{14}$ type 2 diabetes, ${ }^{15}$ neurological disease, ${ }^{16}$ and cancer ${ }^{17}$ have been associated with a shorter telomere length, an emerging literature implicates depression, highly prevalent in older adults, as a potential pathway toward accelerated aging. Prior work has identified relations of depression to age-related diseases such as diabetes, ${ }^{34}$ metabolic disorders, ${ }^{35}$ coronary heart disease, ${ }^{36}$ cognitive impairments/dementia, ${ }^{37}$ and cancer. ${ }^{38}$ In addition, depression could also be a risk factor for mortality in aging. ${ }^{39}$ Although the biological mechanisms mediating these associations remain unclear, accelerated biological aging is a potential mechanism of such increased risk, and this process is thought to occur at the level of telomeres.

Over the past few years, a number of studies have measured the mean telomere length from individuals with major depressive disorder (MDD), and have found evidence for accelerated telomere shortening in the disease. Simon et $\mathrm{al}^{40}$ found that individuals with either major depression or bipolar disorder had shorter telomere length as compared to age-matched controls after adjustments for age, sex, and a lifetime smoking history, with an overall mean difference of $660 \mathrm{bp}$, corresponding to approximately 10 years of accelerated aging in those with mood disorders, assuming an average yearly attrition of 59 bp. ${ }^{41}$ In a sample of Taiwanese patients, those with major depression had significantly shorter telomere length compared to community controls after controlling for age and sex. ${ }^{42}$ The association between major depression and shortened telomeres were further replicated in other samples of patients with MDD. ${ }^{43-45}$ Recently, in a large sample of 11,647 women, recurrent major depression was associated with shorter telomere length. ${ }^{46}$ In addition, the chronicity of depression has been observed to be inversely associated with telomere length. In a previous study where only marginal association between current major depression disorder and telomere length was found, a significant inverse relationship was observed between total cumulative lifetime duration of depression and telomere length, with the mean difference of $281 \mathrm{bp}$, reflecting approximately 7 years of accelerated aging in those with cumulative lifetime depression. ${ }^{47}$ This suggests that telomere shortening may progress with longer exposure to depression. This is 
supported by the study of Elvsashagen et $\mathrm{al}^{48}$ who evaluated the correlation between lifetime depressive episodes and telomere length in patients with bipolar II disorder as compared with healthy age, sex, and education-matched controls; where there was a positive correlation between lifetime number of depressive episodes and the percentage of short telomeres. In the Netherlands Study of Depression and Anxiety, Verhoeven et al extended these findings by showing that both higher depression severity and longer symptom duration in the past 4 years were associated with shorter telomere length. ${ }^{49}$ Similarly, another study demonstrated that a history of depression was also associated with shortened telomeres, independent of the severity of depressive symptoms. ${ }^{50}$ Finally, in a recent meta-analysis using data from 25 studies found a significant but small association between depression and shorter telomere length. ${ }^{51}$

Although there appears to be a significant association between depression and shorter telomeres, some studies reported mixed results. In a sample of older patients with coronary heart disease, MDD was associated with shorter telomere length after adjustment for age and sex, but this association was attenuated after further adjustment for body mass index, smoking, diabetes, left ventricular ejection fraction, statin use, antidepressant use, physical activity, and anxiety. Furthermore, the baseline MDD was not predictive of a 5-year change in telomere. ${ }^{52}$ Malan et al ${ }^{53}$ evaluated the relationship between telomere length and the development of MDD in women who were the victims of rape and found no significant associations of relative telomere length with preexisting MDD or the development of MDD after a 3-month follow-up. Other studies have also failed to demonstrate any significant association between MDD and telomere length (Table 1). ${ }^{54,55}$

Apart from MDD, several studies have examined depressive symptoms and the risk of developing depression in the context of telomere shortening, but the results have been mixed. In the West of Scotland Twenty-07 Study, depressive symptoms were longitudinally associated with shorter telomere length in younger adults, but not in the middle- or older-aged groups. ${ }^{56}$ Gotlib et $a l^{57}$ found that children at familial risk of developing depression had significantly shorter telomere length than did their low-risk counterparts. However, another study found no association between depressive symptoms and telomere length in a cohort of older patients with chronic heart failure, although there was a negative relationship between perceived mental health and telomere length. ${ }^{58}$ Furthermore, depressive symptoms were neither cross-sectionally nor longitudinally associated with telomere length in a sample of older men aged 70 years and over. ${ }^{59}$ Collectively, there may be a link between depression and shorter telomeres; however, the data was still inconclusive.

\section{Potential mechanisms mediating the relationship between depression and telomere shortening}

The exact mechanisms that may underlie the association between depression and accelerated telomere shortening have yet to be fully elucidated, but oxidative stress and chronic inflammation are two important biochemical pathways that are dysregulated in depressed individuals, and may contribute to the depressed state itself and to accelerated aging. Epidemiological studies have reported associations of depression with increased oxidative stress ${ }^{60-63}$ and inflammatory markers such as $\mathrm{C}$-reactive protein and pro-inflammatory cytokines. ${ }^{64,65} \mathrm{~A}$ meta-analysis further demonstrated that not only were inflammatory markers positively associated with depression; there was also a dose-response relationship between them, in which an increased inflammatory state was associated with increased depressive mood. ${ }^{66}$ Oxidative stress has a negative effect on telomere length maintenance, both through the inhibition of telomerase activity ${ }^{67}$ and direct erosion of telomeric DNA.$^{68}$ Conversely, antioxidants prolong telomerase activity and decelerate telomere shortening. ${ }^{69}$ Chronic inflammation enhances turnover of leukocyte, which may reduce telomerase activity and telomere length. For example, an inverse association has been observed between $\mathrm{C}$-reactive protein and telomere length in a sample of older adults. ${ }^{70}$ Pro-inflammatory cytokines have also been shown to regulate telomerase activity in cultured cells, ${ }^{71}$ which may influence telomere length.

However, oxidative stress and chronic inflammation are not the only potential mediators involved in the accelerated telomere shortening in depressed individuals, other pathways such as dysregulated hypothalamus-pituitaryadrenal (HPA) axis and the altered neuroendocrine stress response may play a role as well. ${ }^{72,73}$ Increasing evidence for hyperactivity of the HPA axis as indicated by increased cortisol secretion among depressed individuals has been reported ${ }^{74}$ whereas higher cortisol levels have been associated with reduced telomerase activity ${ }^{75}$ and shorter telomere length. ${ }^{76}$ Higher cortisol levels may also exacerbate oxidative stress and pro-inflammatory cytokines release. ${ }^{77}$ However, a recent study demonstrated that hypocortisolemia was associated with shorter telomere length. ${ }^{44}$ Indeed, 
Table I Studies of depression/depressive symptoms and telomeres

\begin{tabular}{|c|c|c|c|c|c|c|}
\hline Reference & Design & Sample & $\begin{array}{l}\text { Sample size } \\
\text { Full sample } \\
\text { (patient/control) }\end{array}$ & $F(\%)$ & $\begin{array}{l}\text { Age (year) } \\
\text { Full sample } \\
\text { (patient/control) }\end{array}$ & $\begin{array}{l}\text { Telomere length } \\
\text { Full sample } \\
\text { (patient/control) }\end{array}$ \\
\hline 40 & Cross-sectional & MDD + BPD and control & $88(44 / 44)$ & 45 & $50.8(5 \mathrm{I} .1 / 50.5)$ & $7.3 \mathrm{I}(6.98 / 7.64) \mathrm{kb}$ \\
\hline 42 & Cross-sectional & MDD and control & $664(253 / 4 I I)$ & 59 & $(44.5 / 45.3)$ & $(8.17 / 9.13) \mathrm{kb}$ \\
\hline 43 & Cross-sectional & MDD and control & $74(54 / 20)$ & 57 & 49.1 & $(7.20 / 7.55) \mathrm{kb}$ \\
\hline 44 & Cross-sectional & MDD and control & $542(9 \mid / 45 I)$ & 52 & $(60.4 / 58.9)$ & $(5.26 / 5.54) \mathrm{kb}$ \\
\hline 45 & Cross-sectional & MDD and control & $57(9 / 48)$ & - & $18-64$ & $\begin{array}{l}\text { (87.9/I0I.2) } \\
\text { (Telomere content) }\end{array}$ \\
\hline 46 & Cross-sectional & MD and control & I I,647 (5,864/5,783) & 100 & $(30-60 / 40-60)$ & - \\
\hline 47 & Cross-sectional & MDD and control & $\begin{array}{l}\text { Total sample: } 35 \text { (18/17) } \\
\text { Sub-sample: } 27(10 / 17) \\
\text { (In the sub-sample } 10 \\
\text { Individuals had greater } \\
\text { lifetime duration of } \\
\text { major depression) }\end{array}$ & 66 & $(36.8 / 36.6)$ & $\begin{array}{l}\text { Total sample: } \\
(5.1 / 5.1) \mathrm{kb} \\
\text { Sub-sample: } \\
(4.8 / 5.1) \mathrm{kb}\end{array}$ \\
\hline 48 & Cross-sectional & BD-II and control & $56(28 / 28)$ & 68 & $34.8(34.8 / 34.8)$ & - \\
\hline 49 & Cross-sectional & $\begin{array}{l}\text { Current + remitted MDD } \\
\text { and control }\end{array}$ & $\begin{array}{l}\text { 2,407 (current } \\
\text { MDD I,095 + } \\
\text { remitted MDD 802/5I0) }\end{array}$ & 66.8 & $\begin{array}{l}\text { (Current MDD } \\
\text { 40.7, remitted } \\
\text { MDD 43.5/40.5) }\end{array}$ & $\begin{array}{l}\text { (Current MDD 5.6, } \\
\text { remitted } \\
\text { MDD 5.5/5.5) kb }\end{array}$ \\
\hline 50 & Cross-sectional & $\begin{array}{l}\text { A history of unipolar } \\
\text { depression and control }\end{array}$ & $94(44 / 50)$ & 100 & $(53.1-53.8 / 51.1)$ & - \\
\hline 52 & Longitudinal & $\begin{array}{l}\text { MDD with stable } \\
\text { coronary heart } \\
\text { disease and control }\end{array}$ & $\begin{array}{l}\text { Baseline: } 952(206 / 746) \\
5 \text { year follow-up: } \\
608(\mid 27 / 48 I)\end{array}$ & Baseline: 18.6 & $\begin{array}{l}\text { Baseline: } \\
(61.7 / 68.1)\end{array}$ & $\begin{array}{l}\text { Baseline: } \\
(0.86 / 0.89) \mathrm{kb}\end{array}$ \\
\hline 53 & Longitudinal & $\begin{array}{l}\text { Rape survivors with } \\
\text { and without MDD }\end{array}$ & $\begin{array}{l}\text { Baseline: } 63 \text { (23/40) } \\
3 \text { m follow-up: } 63 \text { (3l/32) }\end{array}$ & 100 & 22.3 & - \\
\hline 54 & Cross-sectional & $\begin{array}{l}\text { Current late-life } \\
\text { depression and } \\
\text { never-depressed }\end{array}$ & $483(355 / / 28)$ & 65 & 70.5 & $(5.039 / 5.048) \mathrm{kb}$ \\
\hline 55 & Cross-sectional & MDD and control & $332(166 / 166)$ & 54 & $4 \mid .3(4|.3 / 4| .3)$ & $(9.1 / 8.9) \mathrm{kb}$ \\
\hline 56 & Longitudinal & General population & $\begin{array}{l}\text { I,063 (337 aged } 37,44 \mathrm{I} \\
\text { aged } 57,285 \text { aged } 76)\end{array}$ & Baseline: 55 & Baseline: 55.7 & Baseline: 0.8 kb \\
\hline 57 & Cross-sectional & $\begin{array}{l}\text { Girls had mothers with } \\
\text { no current or past Axis I } \\
\text { disorder and girls had } \\
\text { mothers with a history } \\
\text { of recurrent episodes } \\
\text { of depression }\end{array}$ & $97(50 / 47)$ & 100 & $12.0 / 12.0$ & - \\
\hline 58 & Cross-sectional & $\begin{array}{l}\text { Patients with chronic } \\
\text { heart failure }\end{array}$ & $\begin{array}{l}890(299 / 536) \\
\text { (No in the sub-groups } \\
\text { may not sum up to the total) }\end{array}$ & 39 & 73 & $\begin{array}{l}0.69 \\
T / S \text { ratio }\end{array}$ \\
\hline 59 & Longitudinal & $\begin{array}{l}\text { Elderly men in } \\
\text { general population }\end{array}$ & $\begin{array}{l}\text { Baseline: 171 } \\
\text { Follow-up: } 75\end{array}$ & 0 & $\begin{array}{l}\text { Baseline: } 78 \\
\text { Follow-up: } 84\end{array}$ & $\begin{array}{l}\text { Baseline: } 5.0 \mathrm{~kb} \\
\text { Follow-up: } 4.8 \mathrm{~kb}\end{array}$ \\
\hline
\end{tabular}




\begin{tabular}{|c|c|c|c|}
\hline $\begin{array}{l}\text { Mean } \\
\text { difference }\end{array}$ & $P$-value & Adjustment & Key results \\
\hline $660 \mathrm{bp}$ & 0.002 & Age, sex, smoking, and mood disorder & MDD was associated with shorter telomere length \\
\hline 960 bp & $<0.001$ & $\begin{array}{l}\text { Sex, age, Apo E2, and MAOA } \\
\text { promoter polymorphism }\end{array}$ & MDD was associated with shorter telomere length \\
\hline $350 \mathrm{bp}$ & 0.007 & Nil & MDD was associated with shorter telomere length \\
\hline 277 bp & 0.001 & Age and sex & MDD was associated with shorter telomere length \\
\hline- & 0.002 & - & $\begin{array}{l}\text { MDD group had a significantly decreased mean } \\
\text { telomere content compared with control subjects }\end{array}$ \\
\hline- & - & - & $\begin{array}{l}\text { MD was associated with shorter mean telomere } \\
\text { length (OR: } 0.85,95 \% \mathrm{Cl}: 0.8 \mathrm{I}-0.89)\end{array}$ \\
\hline $\begin{array}{l}\text { Total sample: } \\
40 \text { bp } \\
\text { Sub-sample: } \\
28 \text { I bp }\end{array}$ & $\begin{array}{l}\text { Total sample: } 0.66 \\
\text { Sub-sample: } 0.05\end{array}$ & $\begin{array}{l}\text { Total sample: age and sex } \\
\text { Sub-sample: age, sex, lifetime, and } \\
\text { current tobacco use and BMI }\end{array}$ & $\begin{array}{l}\text { Chronic courses of MD had significantly shorter } \\
\text { telomeres than control subjects }\end{array}$ \\
\hline 552 bp & 0.08 & - & $\begin{array}{l}\text { BD-II was associated with an increased load } \\
\text { of short telomeres }\end{array}$ \\
\hline- & $\begin{array}{l}\text { Current MDD vs control: } 0.027 \\
\text { Remitted MDD vs control: } 0.036\end{array}$ & $\begin{array}{l}\text { Age, sex, education, BMI, smoking, } \\
\text { alcohol use, physical activity and } \\
\text { somatic disease }\end{array}$ & MDD was associated with shorter telomere length \\
\hline- & $<0.01$ & Age & $\begin{array}{l}\text { Individuals with a history of depression } \\
\text { showed significantly shorter telomeres }\end{array}$ \\
\hline $\begin{array}{l}\text { Baseline: } \\
0.03 \mathrm{~kb}\end{array}$ & $\begin{array}{l}\text { Cross-sectional: } 0.06 \\
\text { Longitudinal: compared with } \\
\text { control subjects, those with MDD } \\
\text { at baseline were less likely to } \\
\text { experience telomere shortening } \\
\text { and more likely to experience } \\
\text { telomere lengthening after } \\
\text { adjustment }(P=0.40)\end{array}$ & $\begin{array}{l}\text { Age, sex, diabetes, BMI, smoking, } \\
\text { left ventricular ejection fraction, } \\
\text { statin use, physical inactivity, } \\
\text { antidepressant use and anxiety }\end{array}$ & $\begin{array}{l}\text { MDD was not predictive of } 5 \text {-year change in } \\
\text { telomere length after adjustment for } \\
\text { covariates and baseline telomere length }\end{array}$ \\
\hline- & $\begin{array}{l}\text { Baseline: } 0.21 \\
3 \mathrm{~m} \text { follow-up: } 0.93\end{array}$ & - & $\begin{array}{l}\text { No significant associations were observed } \\
\text { between telomere length and the development } \\
\text { of MDD at either baseline or after } 3 \text { months }\end{array}$ \\
\hline $0.009 \mathrm{~kb}$ & 0.82 & $\begin{array}{l}\text { Age, sex, years of education, } \\
\text { number of cigarette years, alcohol } \\
\text { use, physical activity, BMI, and } \\
\text { number of chronic disease }\end{array}$ & $\begin{array}{l}\text { Late-life depression was not associated telomere } \\
\text { length }\end{array}$ \\
\hline $0.2 \mathrm{~kb}$ & $0.65-0.91$ & - & MDD was not associated with telomere length \\
\hline- & $\begin{array}{l}\text { Baseline: } 0.012-0.013 \\
\text { (in the youngest } 37 \text {-year-old } \\
\text { cohort only) }\end{array}$ & $\begin{array}{l}\text { Sex, social class, assay plate, and } \\
\text { medication use }\end{array}$ & $\begin{array}{l}\text { Average depression symptoms and their change } \\
\text { over time were negatively associated with } \\
\text { telomere length, but on in the youngest cohort } \\
\text { ( } 37 \text { years) }\end{array}$ \\
\hline- & $<0.001$ & $\begin{array}{l}\text { Age, tanner stage, and child } \\
\text { Depression Inventory }\end{array}$ & $\begin{array}{l}\text { Girls of depressed mother (high risk group) had } \\
\text { shorter telomere length than their low-risk peers }\end{array}$ \\
\hline- & 0.51 & - & $\begin{array}{l}\text { Depressive symptoms were not associated } \\
\text { with telomere length }\end{array}$ \\
\hline- & $\begin{array}{l}\text { Baseline: } 0.37-0.78 \\
\text { Follow-up: } 0.96\end{array}$ & $\begin{array}{l}\text { Age, living arrangement, smoking } \\
\text { status, alcohol consumption, physical } \\
\text { activity, chronic disease, and BMI }\end{array}$ & $\begin{array}{l}\text { Depressive symptoms were not associated } \\
\text { with telomere length in both cross-sectional } \\
\text { and longitudinal analyses }\end{array}$ \\
\hline
\end{tabular}

Abbreviations: BMI, body mass index; vs, versus; OR, odds ratio; $\mathrm{Cl}$, confidence interval; MDD, major depressive disorder; BPD, borderline personality disorder; MD, major depression; MAOA, monoamine oxidase A, Apo E2, apolipoprotein E2; BD-II, Bipolar II disorder 
lower cortisol levels have also been reported among older depressed individuals, particularly among those with physical frailty, ${ }^{78}$ suggesting that physical frailty may exhaust the stress response potentially resulting in hypoactivity of the HPA axis, or lower cortisol levels. ${ }^{78,79}$ Therefore, further research is necessary to examine the underlying pathway that accounts for both hyperactivity and hypoactivity of the HPA axis with depression, and their associations with telomere shortening (Figure 1).

\section{Psychological stress and unhealthy lifestyle behaviors as potential moderators}

Psychological stress, the most significant predictor of depression $^{80}$ and unhealthy lifestyle behaviors that are more common among the depressed, including smoking, ${ }^{81}$ alcohol intake ${ }^{82}$ unhealthy diet, ${ }^{83}$ physical inactivity, ${ }^{84}$ and poor sleeping quality ${ }^{85}$ have been implicated in contributing to alterations in the biochemical mediators as discussed in the previous section, resulting in telomere shortening and cellular aging (Figure 1).

\section{Psychological stress}

Numerous studies have shown that cumulative exposure to the chronic stress of depression had a central role in telomere length. The first evidence that psychological stress may impact telomere maintenance came from a study which described shorter telomere length in mothers of chronically ill children. ${ }^{86}$ Similar findings were reported by Parks et al, ${ }^{87}$ who reported significantly shorter telomere length in older women with higher levels of perceived stress and stress hormone. The mechanisms by which psychological stress impacts the body at the cellular level are unknown, but studies have reported that stress is associated with the release of glucocorticoid hormones, which have been shown to reduce the levels of antioxidant, and may, therefore, cause increased oxidative damage to $\mathrm{DNA}^{88}$ and accelerated telomere shortening. ${ }^{68}$

\section{Unhealthy lifestyle behaviors}

Smoking was associated with an increased oxidative stress as well as with inflammatory response, ${ }^{89}$ both of which can induce DNA damage and may expedite telomere shortening. ${ }^{68,90}$ Telomeres in smokers have been shown to be significantly shorter than those in the never- or ex-smokers categories of the same age group. ${ }^{91}$ There was also a dose-effect relationship between the cumulative long-life exposure to tobacco smoking and telomere length. ${ }^{92}$ In addition, active smoking has been associated with accelerated telomere shortening. ${ }^{93}$

Similarly, heavy alcohol consumption was associated with increased oxidative stress and inflammation, ${ }^{94}$ and both processes may enhance telomere shortening. However, evidence from population-based studies on the relation between alcohol intake and telomere length has been limited and inconsistent. Previous studies have noted that alcohol abusers had significantly shorter telomere length compared with controls. ${ }^{95,96}$ However, other studies, that examined the relationship between alcohol intake and telomere length have found $\mathrm{no}^{25,97}$ or marginal associations. ${ }^{98}$ In a recent longitudinal sample of 4,576 general population individuals, alcohol intake was not associated with telomere length either cross-sectionally or longitudinally. ${ }^{99,100}$ Discrepant findings may have resulted from differences in the patterns of alcohol intake. A meta-analysis suggested that heavy, irregular drinking could modify the favorable effect of alcohol intake on the risk of coronary heart disease. ${ }^{101}$
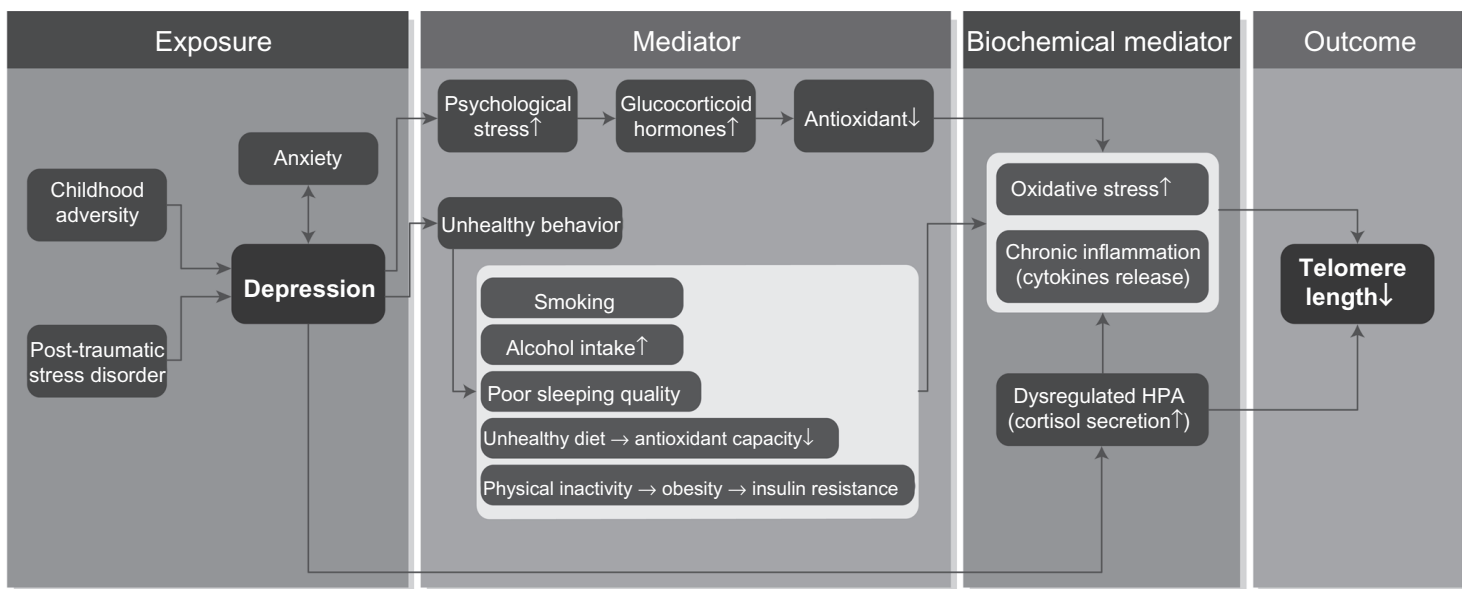

Figure I Schematic model of pathways linking depression and telomere shortening. Note: The relationships are possibly interrelated and bidirectional. 
Associations between dietary factors and telomere length have also been examined previously. A number of studies have reported eating processed meats, ${ }^{102,103}$ and food high in polyunsaturated fats ${ }^{99}$ or saturated fatty acids ${ }^{104}$ were associated with shorter telomere length, whereas high intake of vegetables and fruits, ${ }^{105}$ omega-3 fatty acids, ${ }^{106}$ fiber, ${ }^{99,107}$ vitamins, ${ }^{99,108-112}$ or Chinese green tea ${ }^{113}$ were related to longer telomere length. These observations have led to a belief that the association between depression and telomere length may be moderated in part by dietary factors. The mechanisms by which dietary factors impact the body at the cellular level are unknown, but antioxidant capacity may play a role. Diet rich in antioxidants may maintain the telomeres, via the modulation of oxidative stress and inflammatory reactions. ${ }^{114}$ Micronutrients like vitamin $\mathrm{C}, \mathrm{E}$, folic acid, and marine omega 3 fatty acids are associated with anti-oxidative function, and thereby may be associated with long telomeres due to their anti-oxidative properties. ${ }^{115}$ In a recent study on children and adolescent populations, higher dietary total antioxidants has also been associated with longer telomere length. ${ }^{116}$ Red meat, refined grains, and sugar-sweetened soft drinks, however, may be associated with oxidative stress and inflammation, ${ }^{117-119}$ which could impact cellular aging.

Increasing evidence also suggests that physical inactivity has an adverse effect on telomeres, ${ }^{120,121}$ whereas increasing physical activity has been associated with longer telomere length. ${ }^{121}$ The mechanisms by which physical activity impacts the body at the cellular level have not yet been fully elucidated. One possibility is that physical activity acts via reduction of obesity and prevention of insulin resistance. This could have favorable effects on telomere length, ${ }^{122}$ possibly through the modulation of oxidative stress and inflammatory responses. ${ }^{123}$ Furthermore, physical activity may help to buffer the effects of chronic stress on telomere length. ${ }^{24}$

Disrupted sleep quality has also been associated with shorter telomere length. ${ }^{125-127}$ The biological mechanisms underlying the association between sleep quality and telomere attribution remain to be elucidated. Indeed, disrupted sleep quality has been associated with elevated pro-inflammatory cytokine production, ${ }^{126}$ cortisol secretion, ${ }^{128}$ and enhanced autonomic activation, ${ }^{129}$ which may contribute to telomere shortening.

\section{Other potential moderators}

A growing body of literature suggests that childhood adversity, post-traumatic stress disorder, and anxiety may have considerable impacts on cellular aging. Both childhood adversity and post-traumatic stress disorder have been suggested to be predisposing factors to the development of depression and anxiety, ${ }^{130,131}$ which often coexist with each other, ${ }^{132}$ suggesting that these factors may moderate the association between depression and telomere shortening, possibly by influencing the biochemical mediators as discussed in the previous section (Figure 1).

\section{Childhood adversity}

Several studies have reported an association between childhood adversity and levels of pro-inflammatory cytokines ${ }^{133}$ and cortisol levels, ${ }^{134}$ as well as telomere length in adulthood $^{135-138}$ and in older adults, ${ }^{133,139}$ suggesting that childhood adversity has an impact on aging at the cellular level, although another study did not find an association. ${ }^{140}$ Recent studies also suggested that childhood adversity might even accelerate telomere shortening during childhood. Drury et $\mathrm{al}^{141}$ found that greater exposure to institutional care correlated with reduced buccal cell telomere length in children aged 6-10 years. In a prospective longitudinal study, children who experienced two or more kinds of violence exposure showed significantly more telomere erosion over 5 years, even after adjusting for confounders. ${ }^{142}$ Therefore, there is some evidence of a relationship between childhood adversity and telomere length.

\section{Post-traumatic stress disorder}

Accumulating evidence indicates that individuals with post-traumatic stress disorder, a trauma-related disorder that may develop after exposure to one or more traumatic events, ${ }^{143}$ may be susceptible to accelerated telomere shortening, ${ }^{137,144}$ as indicated by the shortened telomere length. The authors of the later study suggested this effect was largely determined by the presence of substantial adverse childhood events. ${ }^{137}$ Among military personnel, middle-aged war veterans with current post-traumatic stress disorder had a shorter telomere length compared with age-matched healthy controls. ${ }^{145}$ This finding was replicated by Zhang et al ${ }^{146}$ in a sample of army special operations personnel. However, one study evaluated male soldiers with post-traumatic stress disorder and found that the development of post-traumatic stress disorder symptoms was associated with telomere lengthening. ${ }^{147}$ Therefore, the association between posttraumatic stress disorder and telomere length lacks consistent support from the literature.

\section{Anxiety}

Preliminary evidence has also suggested an association between anxiety and shorter telomere length. In one study 
of individuals with various anxiety-type disorders, only older individuals (48-87 years old) showed shortened telomere length compared with age-matched controls, suggesting that more chronic exposure to the disorder was required for the telomere shortening to be observed. ${ }^{136}$ In another study on phobic individuals, only those with more severe symptoms showed telomere shortening. ${ }^{148}$ In contrast, Surtees et al ${ }^{138}$ did not observe significant differences in telomere length in the presence of either a 12-month or a lifetime generalized anxiety disorder among 4,441 women (aged 41-80 years). These discrepant findings may be due to different ascertainment methods of diagnoses and reflecting different samples' characteristics. Therefore, findings remain inconclusive regarding telomere shortening in anxiety disorder.

\section{Conclusion and prospects for interventions}

Telomere length is a robust indicator of "biological age" and may represent a biomarker for assessing an individual's cumulative exposure to depression. A growing body of research demonstrates that individuals diagnosed with MDD have shortened telomere length, which may underlie the association between depression and increased rate of age-related diseases. The potential biochemical pathways by which depression affects telomere length have been discussed, including oxidative and inflammatory stress, alternations in the HPA axis, and cortisol levels. These biochemical mediators could be influenced by several potential moderators associated with depression, including psychological stress and unhealthy lifestyle behaviors. However, these mechanisms remained to be clarified. Furthermore, the associations of telomere length with childhood abuse, post-traumatic stress disorder, and anxiety that are also potential moderators of depression have also been reviewed.

Accepting the pathophysiological role of the biochemical mediators and moderators described above in the relationship between depression and telomere length, interventions that may affect the telomere maintenance system should be considered. A number of stress reduction and lifestyle interventions have shown to favorably impact telomere length or telomerase activity. For example, stress reduction and meditations may reduce cognitive stress and stress arousal and increase positive states of mind and hormonal factors, which could, in turn, promote telomere maintenance. ${ }^{149}$ Exercise may also confer health benefits by enhancing immune and metabolic regulation, preventing insulin resistance as well as buffering the deleterious effects of stress, which could have favorable effects on telomere length. ${ }^{124}$ A 3-month intervention with lifestyle changes including a plant-based diet, moderate exercise, stress management, and social support has been associated with increased telomerase activity. ${ }^{150}$ Similarly, a combination of healthy behaviors, defined by low-risk healthy lifestyle factors for chronic disease, was also associated with longer telomeres in community and clinical samples. ${ }^{98,151}$ Therefore, further studies should examine whether these interventions may be suitable for individuals with depression, resulting not only in a reversal of depressive symptoms but also in decelerating telomere shortening, reversing cellular aging, and reducing the risk of age-related diseases.

\section{Disclosure}

The authors report no conflicts of interest in this work.

\section{References}

1. O'Sullivan RJ, Karlseder J. Telomeres: protecting chromosomes against genome instability. Nat Rev Mol Cell Biol. 2010;11(3):171-181.

2. Blackburn EH. Telomere states and cell fates. Nature. 2000;408(6808): $53-56$.

3. Blackburn EH. Switching and signaling at the telomere. Cell. 2001; 106(6):661-673.

4. Blackburn EH. The end of the (DNA) line. Nat Struct Biol. 2000;7(10): 847-850.

5. Gomez DE, Armando RG, Farina HG, et al. Telomere structure and telomerase in health and disease (review). Int J Oncol. 2012;41(5): 1561-1569.

6. Greider CW. Telomerase activity, cell proliferation, and cancer. Proc Natl Acad Sci U S A. 1998;95(1):90-92.

7. Zhu H, Belcher M, van der Harst P. Healthy aging and disease: role for telomere biology? Clin Sci (Lond). 2011;120(10):427-440.

8. Barrett EL, Richardson DS. Sex differences in telomeres and lifespan. Aging Cell. 2011;10(6):913-921.

9. Gardner M, Bann D, Wiley L, et al. Gender and telomere length: systematic review and meta-analysis. Exp Gerontol. 2014;51:15-27.

10. Mathon NF, Lloyd AC. Cell senescence and cancer. Nat Rev Cancer. 2001;1(3):203-213.

11. Wong JM, Collins K. Telomere maintenance and disease. Lancet. 2003;362(9388):983-988.

12. Ma SL, Lau ES, Suen EW, et al. Telomere length and cognitive function in southern Chinese community-dwelling male elders. Age Ageing. 2013;42(4):450-455.

13. Woo J, Yu R, Tang N, Leung J. Telomere length is associated with decline in grip strength in older persons aged 65 years and over. Age. 2014;36(5).

14. Samani NJ, van der Harst P. Biological ageing and cardiovascular disease. Heart. 2008;94(5):537-539.

15. Sampson MJ, Winterbone MS, Hughes JC, Dozio N, Hughes DA. Monocyte telomere shortening and oxidative DNA damage in type 2 diabetes. Diabetes Care. 2006;29(2):283-289.

16. Honig LS, Schupf N, Lee JH, Tang MX, Mayeux R. Shorter telomeres are associated with mortality in those with APOE epsilon 4 and dementia. Ann Neurol. 2006;60(2):181-187.

17. Willeit $\mathrm{P}$, Willeit J, Mayr A, et al. Telomere length and risk of incident cancer and cancer mortality. JAMA. 2010;304(1):69-75.

18. Sahin E, Colla S, Liesa M, et al. Telomere dysfunction induces metabolic and mitochondrial compromise. Nature. 2011;470(7334):359-365.

19. Jaskelioff M, Muller FL, Paik JH, et al. Telomerase reactivation reverses tissue degeneration in aged telomerase-deficient mice. Nature. 2011;469(7328):102-106. 
20. Cawthon RM, Smith KR, O’Brien E, Sivatchenko A, Kerber RA. Association between telomere length in blood and mortality in people aged 60 years or older. Lancet. 2003;361(9355):393-395.

21. Bakaysa SL, Mucci LA, Slagboom PE, et al. Telomere length predicts survival independent of genetic influences. Aging Cell. 2007;6(6): 769-774.

22. Kimura M, Hjelmborg JV, Gardner JP, et al. Telomere length and mortality: a study of leukocytes in elderly Danish twins. Am JEpidemiol. 2008;167(7):799-806.

23. Bischoff C, Petersen HC, Graakjaer J, et al. No association between telomere length and survival among the elderly and oldest old. Epidemiology. 2006;17(2):190-194.

24. Martin-Ruiz CM, Gussekloo J, van Heemst D, von Zglinicki T, Westendorp RG. Telomere length in white blood cells is not associated with morbidity or mortality in the oldest old: a population-based study. Aging Cell. 2005;4(6):287-290.

25. Harris SE, Deary IJ, MacIntyre A, et al. The association between telomere length, physical health, cognitive ageing, and mortality in non-demented older people. Neurosci Lett. 2006;406(3):260-264

26. Rockwood K, Fox RA, Stolee P, Robertson D, Beattie BL. Frailty in elderly people: an evolving concept. CMAJ. 1994;150(4):489-495.

27. Fried LP, Tangen CM, Walston J, et al. Frailty in older adults: evidence for a phenotype. J Gerontol A Biol Sci Med Sci. 2001;56(3):M146-156.

28. Fried LP, Ferrucci L, Darer J, Williamson JD, Anderson G. Untangling the concepts of disability, frailty, and comorbidity: implications for improved targeting and care. J Gerontol A Biol Sci Med Sci. 2004;59(3): 255-263.

29. Leng SX, Xue QL, Tian J, Walston JD, Fried LP. Inflammation and frailty in older women. J Am Geriatr Soc. 2007;55(6):864-871.

30. Barzilay JI, Blaum C, Moore T, et al. Insulin resistance and inflammation as precursors of frailty: the Cardiovascular Health Study. Arch Intern Med. 2007;167(7):635-641.

31. Woo J, Tang NL, Suen E, Leung JC, Leung PC. Telomeres and frailty. Mech Ageing Dev. 2008;129(11):642-648.

32. Collerton J, Martin-Ruiz C, Davies K, et al. Frailty and the role of inflammation, immunosenescence and cellular ageing in the very old: cross-sectional findings from the Newcastle 85+ Study. Mech Ageing Dev. 2012;133(6):456-466.

33. Saum KU, Dieffenbach AK, Muezzinler A, et al. Frailty and telomere length: cross-sectional analysis in 3537 older adults from the ESTHER cohort. Exp Gerontol. 2014;58:250-255.

34. Mezuk B, Eaton WW, Albrecht S, Golden SH. Depression and type 2 diabetes over the lifespan: a meta-analysis. Diabetes Care. 2008;31(12):2383-2390

35. McIntyre RS, Soczynska JK, Konarski JZ, et al. Should depressive syndromes be reclassified as "Metabolic Syndrome Type II"? Ann Clin Psychiatry. 2007;19(4):257-264.

36. Nicholson A, Kuper H, Hemingway H. Depression as an aetiologic and prognostic factor in coronary heart disease: a meta-analysis of 6362 events among 146538 participants in 54 observational studies. Eur Heart J. 2006;27(23):2763-2774.

37. Gao Y, Huang C, Zhao K, et al. Depression as a risk factor for dementia and mild cognitive impairment: a meta-analysis of longitudinal studies Int J Geriatr Psychiatry. 2013;28(5):441-449.

38. Chida Y, Hamer M, Wardle J, Steptoe A. Do stress-related psychosocial factors contribute to cancer incidence and survival? Nat Clin Pract Oncol. 2008;5(8):466-475.

39. Schulz R, Beach SR, Ives DG, Martire LM, Ariyo AA, Kop WJ. Association between depression and mortality in older adults: the Cardiovascular Health Study. Arch Intern Med. 2000;160(12):1761-1768.

40. Simon NM, Smoller JW, McNamara KL, et al. Telomere shortening and mood disorders: preliminary support for a chronic stress model of accelerated aging. Biol Psychiatry. 2006;60(5):432-435.

41. Rufer N, Brummendorf TH, Kolvraa S, et al. Telomere fluorescence measurements in granulocytes and $\mathrm{T}$ lymphocyte subsets point to a high turnover of hematopoietic stem cells and memory T cells in early childhood. J Exp Med. 1999;190(2):157-167.
42. Lung FW, Chen NC, Shu BC. Genetic pathway of major depressive disorder in shortening telomeric length. Psychiatr Genet. 2007;17(3): 195-199.

43. Hartmann N, Boehner M, Groenen F, Kalb R. Telomere length of patients with major depression is shortened but independent from therapy and severity of the disease. Depress Anxiety. 2010;27(12):1111-1116.

44. Wikgren M, Maripuu M, Karlsson T, et al. Short telomeres in depression and the general population are associated with a hypocortisolemic state. Biol Psychiatry. 2012;71(4):294-300.

45. Garcia-Rizo C, Fernandez-Egea E, Miller BJ, et al. Abnormal glucose tolerance, white blood cell count, and telomere length in newly diagnosed, antidepressant-naive patients with depression. Brain Behav Immun. 2013;28:49-53.

46. Cai N, Chang S, Li Y, et al. Molecular signatures of major depression. Curr Biol. 2015;25(9):1146-1156.

47. Wolkowitz OM, Mellon SH, Epel ES, et al. Leukocyte telomere length in major depression: correlations with chronicity, inflammation and oxidative stress - preliminary findings. PLoS One. 2011;6(3):e17837.

48. Elvsashagen T, Vera E, Boen E, et al. The load of short telomeres is increased and associated with lifetime number of depressive episodes in bipolar II disorder. J Affect Disord. 2011;135(1-3):43-50.

49. Verhoeven JE, Revesz D, Epel ES, Lin J, Wolkowitz OM, Penninx BW. Major depressive disorder and accelerated cellular aging: results from a large psychiatric cohort study. Mol Psychiatry. 2014;19(8):895-901.

50. Karabatsiakis A, Kolassa IT, Kolassa S, Rudolph KL, Dietrich DE. Telomere shortening in leukocyte subpopulations in depression. BMC Psychiatry. 2014;14:192.

51. Schutte NS, Malouff JM. The Association between depression and leukocyte telomere length: a meta-analysis. Depress Anxiety. 2015;32(4): 229-238.

52. Hoen PW, de Jonge P, Na BY, et al. Depression and leukocyte telomere length in patients with coronary heart disease: data from the Heart and Soul Study. Psychosom Med. 2011;73(7):541-547.

53. Malan S, Hemmings S, Kidd M, Martin L, Seedat S. Investigation of telomere length and psychological stress in rape victims. Depress Anxiety. 2011;28(12):1081-1085.

54. Schaakxs R, Verhoeven JE, Oude Voshaar RC, Comijs HC, Penninx BW. Leukocyte telomere length and late-life depression. Am J Geriatr Psychiatry. 2015;23(4):423-432.

55. Simon NM, Walton ZE, Bui E, et al. Telomere length and telomerase in a well-characterized sample of individuals with major depressive disorder compared to controls. Psychoneuroendocrinology. 2015;58:9-22.

56. Phillips AC, Robertson T, Carroll D, et al. Do symptoms of depression predict telomere length? Evidence from the west of Scotland twenty-07 study. Psychosom Med. 2013;75(3):288-296.

57. Gotlib IH, LeMoult J, Colich NL, et al. Telomere length and cortisol reactivity in children of depressed mothers. Mol Psychiatry. 2014;20: 615-620.

58. Huzen J, van der Harst P, de Boer RA, et al. Telomere length and psychological well-being in patients with chronic heart failure. Age Ageing. 2010;39(2):223-227.

59. Rius-Ottenheim N, Houben JM, Kromhout D, et al. Telomere length and mental well-being in elderly men from the Netherlands and Greece. Behav Genet. 2012;42(2):278-286.

60. Forlenza MJ, Miller GE. Increased serum levels of 8-hydroxy-2'deoxyguanosine in clinical depression. Psychosom Med. 2006;68(1):1-7.

61. Irie M, Miyata M, Kasai H. Depression and possible cancer risk due to oxidative DNA damage. J Psychiatr Res. 2005;39(6):553-560.

62. Ng F, Berk M, Dean O, Bush AI. Oxidative stress in psychiatric disorders: evidence base and therapeutic implications. Int $J$ Neuropsychopharmcol. 2008;11(6):851-876.

63. Sarandol A, Sarandol E, Eker SS, Erdinc S, Vatansever E, Kirli S. Major depressive disorder is accompanied with oxidative stress: short-term antidepressant treatment does not alter oxidative-antioxidative systems. Hum Psychopharmacol. 2007;22(2):67-73.

64. Schiepers OJG, Wichers MC, Maes M. Cytokines and major depression. Prog Neuropsychopharmacol Biol Psychiatry. 2005;29(2):201-217. 
65. Miller AH, Maletic V, Raison CL. Inflammation and its discontents: the role of cytokines in the pathophysiology of major depression. Biol Psychiatry. 2009;65(9):732-741.

66. Howren MB, Lamkin DM, Suls J. Associations of depression with C-reactive protein, IL-1, and IL-6: a meta-analysis. Psychosom Med. 2009;71(2):171-186.

67. Kurz DJ, Decary S, Hong Y, Trivier E, Akhmedov A, Erusalimsky JD. Chronic oxidative stress compromises telomere integrity and accelerates the onset of senescence in human endothelial cells. J Cell Sci. 2004; 117(Pt 11):2417-2426.

68. von Zglinicki T. Oxidative stress shortens telomeres. Trends Biochem Sci. 2002;27(7):339-344.

69. Haendeler J, Hoffmann J, Diehl JF, et al. Antioxidants inhibit nuclear export of telomerase reverse transcriptase and delay replicative senescence of endothelial cells. Circ Res. 2004;94(6):768-775.

70. Fitzpatrick AL, Kronmal RA, Gardner JP, et al. Leukocyte telomere length and cardiovascular disease in the cardiovascular health study. Am J Epidemiol. 2007;165(1):14-21.

71. Liu JP, Chen SM, Cong YS, et al. Regulation of telomerase activity by apparently opposing elements. Ageing Res Rev. 2010;9(3):245-256.

72. Penninx BW, Beekman AT, Bandinelli S, et al. Late-life depressive symptoms are associated with both hyperactivity and hypoactivity of the hypothalamo-pituitary-adrenal axis. Am J Geriatr Psychiatry. 2007;15(6):522-529.

73. Vreeburg SA, Hoogendijk WJ, van Pelt J, et al. Major depressive disorder and hypothalamic-pituitary-adrenal axis activity: results from a large cohort study. Arch Gen Psychiatry. 2009;66(6):617-626.

74. Otte C, Hart S, Neylan TC, Marmar CR, Yaffe K, Mohr DC. A metaanalysis of cortisol response to challenge in human aging: importance of gender. Psychoneuroendocrinology. 2005;30(1):80-91.

75. Choi J, Fauce SR, Effros RB. Reduced telomerase activity in human T lymphocytes exposed to cortisol. Brain Behav Immun. 2008;22(4): 600-605.

76. Tomiyama AJ, O’Donovan A, Lin J, et al. Does cellular aging relate to patterns of allostasis? An examination of basal and stress reactive HPA axis activity and telomere length. Physiol Behav. 2012;106(1): $40-45$.

77. Sorrells SF, Sapolsky RM. An inflammatory review of glucocorticoid actions in the CNS. Brain Behav Immun. 2007;21(3):259-272.

78. Oldehinkel AJ, van den Berg MD, Flentge F, Bouhuys AL, ter Horst GJ, Ormel J. Urinary free cortisol excretion in elderly persons with minor and major depression. Psychiatry Res. 2001;104(1):39-47.

79. Fries E, Hesse J, Hellhammer J, Hellhammer DH. A new view on hypocortisolism. Psychoneuroendocrinology. 2005;30(10): 1010-1016.

80. Kendler KS, Karkowski LM, Prescott CA. Causal relationship between stressful life events and the onset of major depression. Am J Psychiatry. 1999;156(6):837-841.

81. Wiecha JM, Lee V, Hodgkins J. Patterns of smoking, risk factors for smoking, and smoking cessation among Vietnamese men in Massachusetts (United States). Tob Control. 1998;7(1):27-34.

82. Trim RS, Schuckit MA, Smith TL. Predicting drinking onset with discrete-time survival analysis in offspring from the San Diego prospective study. Drug Alcohol Depend. 2010;107(2-3):215-220.

83. Akbaraly TN, Brunner EJ, Ferrie JE, Marmot MG, Kivimaki M, SinghManoux A. Dietary pattern and depressive symptoms in middle age. $\mathrm{Br}$ J Psychiatry. 2009;195(5):408-413.

84. Patten SB, Williams JV, Lavorato DH, Eliasziw M. A longitudinal community study of major depression and physical activity. Gen Hosp Psychiatry. 2009;31(6):571-575.

85. Coulombe JA, Reid GJ, Boyle MH, Racine Y. Sleep problems, tiredness, and psychological symptoms among healthy adolescents. $J$ Pediatr Psychol. 2011;36(1):25-35.

86. Epel ES, Blackburn EH, Lin J, et al. Accelerated telomere shortening in response to life stress. Proc Natl Acad Sci U S A. 2004;101(49): $17312-17315$
87. Parks CG, Miller DB, McCanlies EC, et al. Telomere length, current perceived stress, and urinary stress hormones in women. Cancer Epidemiol Biomarkers Prev. 2009;18(2):551-560.

88. Irie M, Asami S, Ikeda M, Kasai H. Depressive state relates to female oxidative DNA damage via neutrophil activation. Biochem Biophys Res Commun. 2003;311(4):1014-1018.

89. Burke A, Fitzgerald GA. Oxidative stress and smoking-induced vascular injury. Prog Cardiovasc Dis. 2003;46(1):79-90.

90. Starr JM, Shiels PG, Harris SE, et al. Oxidative stress, telomere length and biomarkers of physical aging in a cohort aged 79 years from the 1932 Scottish Mental Survey. Mech Ageing Dev. 2008;129(12): 745-751.

91. Valdes AM, Andrew T, Gardner JP, et al. Obesity, cigarette smoking, and telomere length in women. Lancet. 2005;366(9486):662-664.

92. Morla M, Busquets X, Pons J, Sauleda J, MacNee W, Agusti AG. Telomere shortening in smokers with and without COPD. Eur Respir J. 2006;27(3):525-528.

93. Huzen J, Wong LS, van Veldhuisen DJ, et al. Telomere length loss due to smoking and metabolic traits. J Intern Med. 2014;275(2):155-163.

94. Albano E. Oxidative mechanisms in the pathogenesis of alcoholic liver disease. Mol Aspect Med. 2008;29(1-2):9-16.

95. Strandberg TE, Strandberg AY, Saijonmaa O, Tilvis RS, Pitkala KH, Fyhrquist F. Association between alcohol consumption in healthy midlife and telomere length in older men. The Helsinki Businessmen Study. Eur J Epidemiol. 2012;27(10):815-822.

96. Pavanello S, Hoxha M, Dioni L, et al. Shortened telomeres in individuals with abuse in alcohol consumption. Int J Cancer. 2011;129(4): 983-992.

97. Hou L, Savage SA, Blaser MJ, et al. Telomere length in peripheral leukocyte DNA and gastric cancer risk. Cancer Epidemiol Biomarkers Prev. 2009;18(11):3103-3109.

98. Mirabello L, Huang WY, Wong JY, et al. The association between leukocyte telomere length and cigarette smoking, dietary and physical variables, and risk of prostate cancer. Aging Cell. 2009;8(4): 405-413.

99. Paul L. Diet, nutrition and telomere length. J Nutr Biochem. 2011; 22(10):895-901.

100. Weischer M, Bojesen SE, Nordestgaard BG. Telomere shortening unrelated to smoking, body weight, physical activity, and alcohol intake: 4,576 general population individuals with repeat measurements 10 years apart. PLoS Genet. 2014;10(3):e1004191.

101. Bagnardi V, Zatonski W, Scotti L, La Vecchia C, Corrao G. Does drinking pattern modify the effect of alcohol on the risk of coronary heart disease? Evidence from a meta-analysis. J Epidemiol Community Health. 2008;62(7):615-619.

102. Nettleton JA, Diez-Roux A, Jenny NS, Fitzpatrick AL, Jacobs DR Jr, Dietary patterns, food groups, and telomere length in the Multi-Ethnic Study of Atherosclerosis (MESA). Am J Clin Nutr. 2008;88(5): 1405-1412.

103. O'Callaghan NJ, Toden S, Bird AR, Topping DL, Fenech M, Conlon MA. Colonocyte telomere shortening is greater with dietary red meat than white meat and is attenuated by resistant starch. Clin Nutr. 2012;31(1):60-64.

104. Kiecolt-Glaser JK, Epel ES, Belury MA, et al. Omega-3 fatty acids, oxidative stress, and leukocyte telomere length: a randomized controlled trial. Brain Behav Immun. 2013;28:16-24.

105. Tiainen AM, Mannisto S, Blomstedt PA, et al. Leukocyte telomere length and its relation to food and nutrient intake in an elderly population. Eur J Clin Nutr. 2012;66(12):1290-1294.

106. Farzaneh-Far R, Lin J, Epel ES, Harris WS, Blackburn EH, Whooley MA. Association of marine omega-3 fatty acid levels with telomeric aging in patients with coronary heart disease. JAMA. 2010; 303(3):250-257.

107. Cassidy A, De Vivo I, Liu Y, et al. Associations between diet, lifestyle factors, and telomere length in women. Am J Clin Nutr. 2010;91(5): 1273-1280. 
108. Richards JB, Valdes AM, Gardner JP, et al. Higher serum vitamin D concentrations are associated with longer leukocyte telomere length in women. Am J Clin Nutr. 2007;86(5):1420-1425.

109. Xu Q, Parks CG, DeRoo LA, Cawthon RM, Sandler DP, Chen H. Multivitamin use and telomere length in women. Am J Clin Nutr. 2009;89(6):1857-1863.

110. Furumoto K, Inoue E, Nagao N, Hiyama E, Miwa N. Age-dependent telomere shortening is slowed down by enrichment of intracellular vitamin C via suppression of oxidative stress. Life Sci. 1998;63(11): 935-948.

111. Tanaka Y, Moritoh Y, Miwa N. Age-dependent telomere-shortening is repressed by phosphorylated alpha-tocopherol together with cellular longevity and intracellular oxidative-stress reduction in human brain microvascular endotheliocytes. J Cell Biochem. 2007;102(3):689-703.

112. Paul L, Cattaneo M, D'Angelo A, et al. Telomere length in peripheral blood mononuclear cells is associated with folate status in men. J Nutr. 2009;139(7):1273-1278.

113. Chan R, Woo J, Suen E, Leung J, Tang N. Chinese tea consumption is associated with longer telomere length in elderly Chinese men Br J Nutr. 2010;103(1):107-113.

114. Maggini S, Wintergerst ES, Beveridge S, Hornig DH. Selected vitamins and trace elements support immune function by strengthening epithelial barriers and cellular and humoral immune responses. Br J Nutr. 2007;98(Suppl 1):S29-S35.

115. Romieu I, Garcia-Esteban R, Sunyer J, et al. The effect of supplementation with omega-3 polyunsaturated fatty acids on markers of oxidative stress in elderly exposed to $\mathrm{PM}(2.5)$. Environ Health Perspect. 2008;116(9):1237-1242.

116. García-Calzón S, Moleres A, Martínez-González MA, et al. Dietary total antioxidant capacity is associated with leukocyte telomere length in a children and adolescent population. Clin Nutr. 2014;pii: S0261-5614(14)00191-5.

117. Montonen J, Boeing H, Fritsche A, et al. Consumption of red meat and whole-grain bread in relation to biomarkers of obesity, inflammation, glucose metabolism and oxidative stress. Eur J Nutr. 2013;52(1): 337-345.

118. Azadbakht L, Esmaillzadeh A. Red meat intake is associated with metabolic syndrome and the plasma $\mathrm{C}$-reactive protein concentration in women. $J$ Nutr. 2009;139(2):335-339.

119. Galland L. Diet and inflammation. Nutr Clin Pract. 2010;25(6): 634-640.

120. Du M, Prescott J, Kraft P, et al. Physical activity, sedentary behavior, and leukocyte telomere length in women. Am J Epidemiol. 2012; 175(5):414-422.

121. Cherkas LF, Hunkin JL, Kato BS, et al. The association between physical activity in leisure time and leukocyte telomere length. Arch Intern Med. 2008;168(2):154-158.

122. Demissie S, Levy D, Benjamin EJ, et al. Insulin resistance, oxidative stress, hypertension, and leukocyte telomere length in men from the Framingham Heart Study. Aging Cell. 2006;5(4):325-330.

123. Keaney JF Jr, Larson MG, Vasan RS, et al. Obesity and systemic oxidative stress: clinical correlates of oxidative stress in the Framingham Study. Arterioscler Thromb Vasc Biol. 2003;23(3):434-439.

124. Puterman E, Lin J, Blackburn E, O’Donovan A, Adler N, Epel E. The power of exercise: buffering the effect of chronic stress on telomere length. PLoS One. 2010;5(5): 10837.

125. Liang G, Schernhammer E, Qi L, Gao X, De Vivo I, Han J. Associations between rotating night shifts, sleep duration, and telomere length in women. PLoS One. 2011;6(8):e23462.

126. Prather AA, Marsland AL, Hall M, Neumann SA, Muldoon MF, Manuck SB. Normative variation in self-reported sleep quality and sleep debt is associated with stimulated pro-inflammatory cytokine production. Biol Psychol. 2009;82(1):12-17.

127. Prather AA, Puterman E, Lin J, et al. Shorter leukocyte telomere length in midlife women with poor sleep quality. J Aging Res. 2011;2011: 721390.
128. Lasikiewicz N, Hendrickx H, Talbot D, Dye L. Exploration of basal diurnal salivary cortisol profiles in middle-aged adults: associations with sleep quality and metabolic parameters. Psychoneuroendocrinology. 2008;33(2):143-151.

129. Zhang J, Ma RC, Kong AP, et al. Relationship of sleep quantity and quality with 24-hour urinary catecholamines and salivary awakening cortisol in healthy middle-aged adults. Sleep. 2011;34(2):225-233.

130. Chapman DP, Whitfield CL, Felitti VJ, Dube SR, Edwards VJ, Anda RF. Adverse childhood experiences and the risk of depressive disorders in adulthood. $J$ Affect Disord. 2004;82(2):217-225.

131. Bleich A, Koslowsky M, Dolev A, Lerer B. Post-traumatic stress disorder and depression. An analysis of comorbidity. Br J Psychiatry. 1997; 170:479-482.

132. Kessler RC, Ruscio AM, Shear K, Wittchen HU. Epidemiology of anxiety disorders. Curr Top Behav Neurosci. 2010;2:21-35.

133. Kiecolt-Glaser JK, Gouin JP, Weng NP, Malarkey WB, Beversdorf DQ, Glaser R. Childhood adversity heightens the impact of later-life caregiving stress on telomere length and inflammation. Psychosom Med. 2011;73(1):16-22.

134. Tyrka AR, Wier L, Price LH, et al. Childhood parental loss and adult hypothalamic-pituitary-adrenal function. Biol Psychiatry. 2008; 63(12):1147-1154

135. Tyrka AR, Price LH, Kao HT, Porton B, Marsella SA, Carpenter LL. Childhood maltreatment and telomere shortening: preliminary support for an effect of early stress on cellular aging. Biol Psychiatry. 2010; 67(6):531-534

136. Kananen L, Surakka I, Pirkola S, et al. Childhood adversities are associated with shorter telomere length at adult age both in individuals with an anxiety disorder and controls. PLoS One. 2010;5(5):e10826.

137. O'Donovan A, Epel E, Lin J, et al. Childhood trauma associated with short leukocyte telomere length in posttraumatic stress disorder. Biol Psychiatry. 2011;70(5):465-471.

138. Surtees PG, Wainwright NW, Pooley KA, et al. Life stress, emotional health, and mean telomere length in the European Prospective Investigation into Cancer (EPIC)-Norfolk population study. J Gerontol A Biol Sci Med Sci. 2011;66(11):1152-1162.

139. Savolainen K, Eriksson JG, Kananen L, et al. Associations between early life stress, self-reported traumatic experiences across the lifespan and leukocyte telomere length in elderly adults. Biol Psychol. 2014;97:35-42.

140. Glass D, Parts L, Knowles D, Aviv A, Spector TD. No correlation between childhood maltreatment and telomere length. Biol Psychiatry. 2010;68(6):e21-e22; author reply e23-e24.

141. Drury SS, Theall K, Gleason MM, et al. Telomere length and early severe social deprivation: linking early adversity and cellular aging. Mol Psychiatry. 2012;17(7):719-727.

142. Shalev I, Moffitt TE, Sugden K, et al. Exposure to violence during childhood is associated with telomere erosion from 5 to 10 years of age: a longitudinal study. Mol Psychiatry. 2013;18(5):576-581.

143. American Psychiatric Association. Diagnostic and Statistical Manual of Mental Sisorders. 5th ed. Arlington, VA: American Psychiatric Publishing; 2013.

144. Ladwig KH, Brockhaus AC, Baumert J, et al. Posttraumatic stress disorder and not depression is associated with shorter leukocyte telomere length: findings from 3,000 participants in the population-based KORA F4 study. PLoS One. 2013;8(7):e64762.

145. Jergovic M, Tomicevic M, Vidovic A, et al. Telomere shortening and immune activity in war veterans with posttraumatic stress disorder. Prog Neuropsychopharmacol Biol Psychiatry. 2014;54:275-283.

146. Zhang L, Hu XZ, Benedek DM, et al. The interaction between stressful life events and leukocyte telomere length is associated with PTSD. Mol Psychiatry. 2014;19(8):855-856.

147. Boks MP, van Mierlo HC, Rutten BP, et al. Longitudinal changes of telomere length and epigenetic age related to traumatic stress and post-traumatic stress disorder. Psychoneuroendocrinology. 2015;51: 506-512. 
148. Okereke OI, Prescott J, Wong JY, Han J, Rexrode KM, De Vivo I. High phobic anxiety is related to lower leukocyte telomere length in women. PLoS One. 2012;7(7):e40516.

149. Epel E, Daubenmier J, Moskowitz JT, Folkman S, Blackburn E. Can meditation slow rate of cellular aging? Cognitive stress, mindfulness, and telomeres. Ann N Y Acad Sci. 2009;1172:34-53.
150. Ornish D, Lin J, Daubenmier J, et al. Increased telomerase activity and comprehensive lifestyle changes: a pilot study. Lancet Oncol. 2008;9(11):1048-1057.

151. Sun Q, Shi L, Prescott J, et al. Healthy lifestyle and leukocyte telomere length in US women. PLoS One. 2012;7(5):e38374.

\section{Publish your work in this journal}

Research and Reports in Biochemistry is an international, peer-reviewed, open access journal publishing original research, reports, reviews and commentaries on all areas of biochemistry. The manuscript management system is completely online and includes a very quick and fair peer-review system. Visit http://www.dovepress.com/testimonials.php to read real quotes from published authors. 